\title{
Botanical ethnoveterinary therapies used by agro-pastoralists of Fafan zone, Eastern Ethiopia
}

\author{
Teka Feyera' ${ }^{1}$ Endalkachew Mekonnen², Befekadu Urga Wakayo ${ }^{1}$ and Solomon Assefa ${ }^{3 *}$
}

\begin{abstract}
Background: In Ethiopia, plant based remedies are still the most important and sometimes the only source of therapeutics in the management of livestock diseases. However, documentation of this indigenous knowledge of therapeutic system still remains at a minimum level. The aim of this study was, thus, to document the traditional knowledge of botanical ethnoveterinary therapies in the agro-pastoral communities of Fafan Zone, Eastern Ethiopia.

Methods: The study employed a cross-sectional participatory survey. Purposive sampling technique was applied to select key respondents with desired knowledge in traditional animal health care system. Data were gathered from a total of 24 (22 males and 2 females) ethnoveterinary practitioners and herbalists using an in-depth-interview complemented with group discussion and field observation.

Results: The current ethnobotanical survey indicated that botanical ethnoveterinary therapies are the mainstay of livestock health care system in the studied communities. A total of 49 medicinal plants belonging to 21 families, which are used by traditional healers and livestock raisers for the treatment of 29 types of livestock ailments/health problems, were identified in the study area. The major plant parts used were leaves (43\%) followed by roots (35\%). In most cases, traditional plant remedies were prepared by pounding the remedial plant part and mixing it with water at room temperature.

Conclusion: The various types of identified medicinal plants and their application in ethnoveternary practice of Fafan zone agro pastoralists indicate the depth of indigenous knowledge in ethnobotanical therapy. The identified medicinal plants could be potentially useful for future phytochemical and pharmacological studies.
\end{abstract}

Keywords: Ethnoveterinary, Medicinal plants, Livestock diseases, Fafan zone, Agro-pastoralist

\section{Background}

Livestock production is an integral part of the Ethiopian agricultural sector that approximately shares $40 \%$ of the national agricultural output [1]. Previously, it was reported that Ethiopia has the largest livestock population in Africa [2]. However, due to the prevailing animal diseases, the economic benefits gained from this sector still remain marginal. Animal diseases are among the principal causes of poor livestock performance and cause of high economic losses in the country $[3,4]$.

\footnotetext{
* Correspondence: Solomon.assefa@aau.edu.et

${ }^{3}$ Department of Pharmacology and Clinical Pharmacy, School of Pharmacy,

Addis Ababa University, Addis Ababa, Ethiopia

Full list of author information is available at the end of the article
}

Conventional veterinary service is still less developed in the country, which is characterized by lack of adequate animal health infrastructure, veterinary clinics, and veterinarians. Furthermore, most modern drugs are expensive and not affordable to the majority of Ethiopian farmers and pastoralists $[5,6]$. The majority of livestock raisers in Ethiopia are far away from the sites of animal clinic stations [7]. These factors make Ethiopian livestock raisers rely on endogenous ethnoveterinary knowledge and practices (mainly botanical products) for the management of diseases of their domestic animals. The traditional remedies are socially acceptable, inexpensive and locally available $[8,9]$.

However, very little of the ethnoveterinary knowledge of Ethiopian famers and pastoralists in relation to the 
use of medicinal plants is so far properly documented and analyzed $[5,6,10]$. It is estimated that up to $90 \%$ of current livestock diseases are managed through the use of traditional medicines [11]. WHO stated: the use of natural products in control of animal and human diseases are considerably effective [12].

In most scenarios, the traditional medical knowledge in Ethiopia is passed verbally from generation to generation. In addition, valuable information can be lost whenever a traditional medical practitioner passes without conveying his/her knowledge on traditional medicinal plants. Similarly, ethnoveterinary practice in the country is being affected by acculturation and depletion of plants as a result of population pressure, drought, environmental degradation, deforestation and over exploitation of the medicinal plants [13, 14]. Consequently, there is a pressing need to document medicinal plants used and the associated indigenous knowledge by conducting ethnobotanical studies $[15,16]$.

Compared to the multiethnic cultural diversity and the diverse flora of Ethiopia, the studies conducted on the traditional ethnoveterinary medicinal plants in Ethiopia are very limited [17]. In recent years, few ethnoveterniary surveys have been conducted in different areas of the country [10, 17-28]. As it is factual throughout the country, in Ethiopian Somali Regional State (ESRS), ethnoveterinary knowledge is believed to be rich and worth documenting. However, there is gap of information on the level, scope, role and limitations of plant based remedies in the traditional animal healthcare system. Thus, this ethnobotanical survey was initiated in view of documenting the indigenous knowledge associated with utilization of botanical ethnoveterinary therapies for the management of livestock ailments among the agropastoralist communities of Fafan Zone, Eastern Ethiopia.

\section{Methods}

\section{Study area}

The study area covers the Babile district and part of Jigjiga district, found in Fafan zone of ESRS (Fig. 1). The zone is situated in the northern part of ESRS. The total land coverage of the zone is $40,861 \mathrm{~km}^{2}$, of which the rangeland extends over $36,629 \mathrm{~km}^{2}$. About $52.6 \%, 31 \%$ and $7 \%$ of the landscape of the zone can be categorized as flat to gentle slopes, hills and steep slope, respectively. Fafan zone comprises pastoralism, agro-pastoralism and sedentary production systems. Agropastoralism (95\%) is the dominant production system in the zone [29].

The zone geographically lies between $8^{\circ} 44^{\prime} \mathrm{N}$ to $11^{\circ} 00^{\prime} \mathrm{N}$ latitude and $40^{\circ} 22^{\prime} \mathrm{E}$ to $44^{\circ} 00^{\prime} \mathrm{E}$ longitude. The altitude of the zone ranges from 500 to $1650 \mathrm{~m}$ above sea level. The mean minimum and maximum temperature ranges from 16 to $20{ }^{\circ} \mathrm{C}$ and
$28-38{ }^{\circ} \mathrm{C}$, respectively [30]. The rainfall distribution in the zone is very erratic with a mean annual rainfall of 600 to $700 \mathrm{~mm}$ [31].

\section{Study design}

A cross-sectional, participatory study was employed to collect ethnoveterinary information from traditional healers in Fafan zone of ESRS between April, 2014 and August, 2015. Indigenous ethno-botanical knowledge, resources and their applications were the main study parameters.

\section{Sampling procedure}

A purposive snowball sampling technique was used to select study participants i.e. ethnopractitioners. This approach aids in acquiring the desired quality and quantity of information on traditional animal health care systems [32]. Ultimately, a total sample of 24 (22 males and 2 female) key respondents were selected.

\section{Ethnobotanical data collection}

Ethnobotanical data were mainly gathered through repeated field trips and investigations, with individual interviews, group discussion, and field observations using the same format used by [33] and [34]. Participant interviews were conducted using semi-structured questionnaires prepared in English and administered in local language (Somali) with the help of competent local translators. Data collected comprise: indications, local name, parts used in traditional remedies, mode of preparation (dosage), and route of administration of each medicinal plant against livestock diseases. Moreover, manner of indigenous knowledge transfer was recorded.

\section{Plant specimen collection and identification}

Ensuing interviews with selected key respondents, a field trip was arranged to identify and collect specimen of reported indigenous medicinal plants from their natural vegetation for further botanical identification. Botanical identification of plant specimens was conducted using herbarium materials and taxonomic keys described in various volumes on the Flora of Ethiopia [35, 36]. For each plant species, voucher specimens were given a collection number and deposited in the National Herbarium, Addis Ababa University.

\section{Enumeration of documented plants}

A list of plants and plant products traditionally used to manage animal health problems in the agro-pastoralist communities of Fafan zone was documented. The documentation compiled their scientific and vernacular names, family names, disease and ill-health conditions treated, target type of livestock and the preparation forms of 


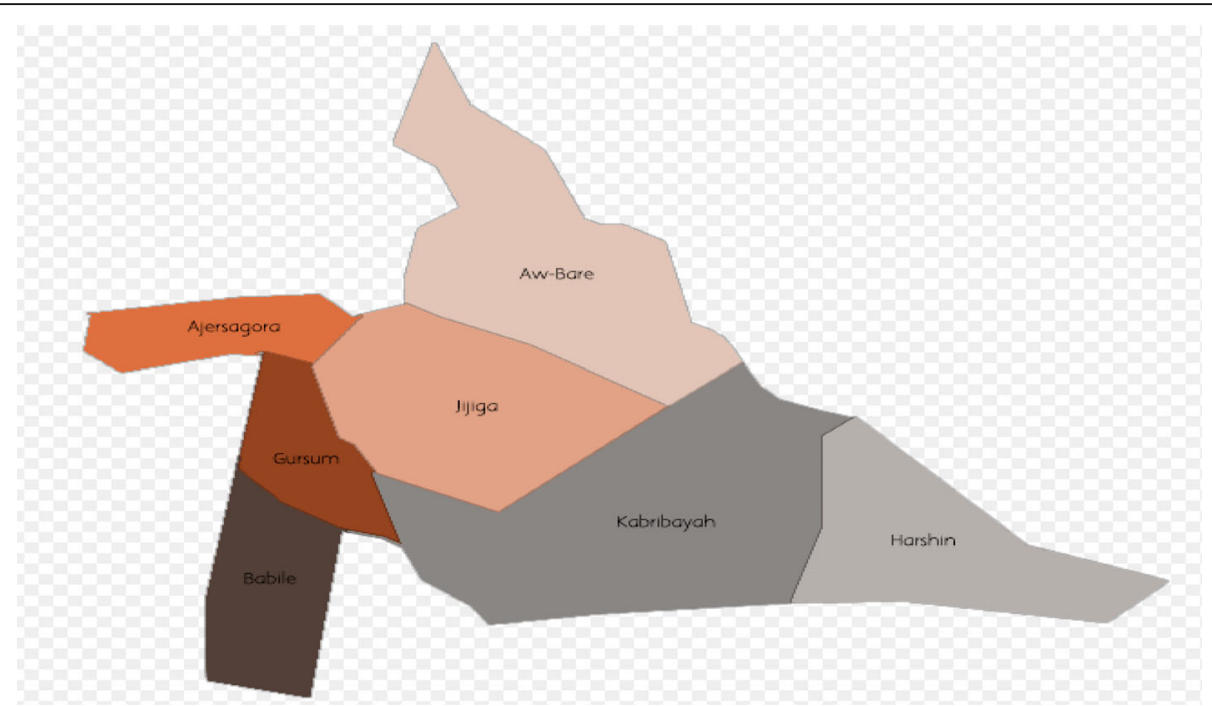

Fig. 1 Map of the study area. @) User: AlaskaLava / Wikimedia Commons / https://commons.wikimedia.org/wiki/File:Fafan_Zone.png\#filelinks / CC-BY-SA-4.0

different remedies (Table 2). The names of plants were arranged according to their alphabetical order.

\section{Data analysis}

Microsoft Excel spreadsheet software was employed for organizing and analyzing the collected ethnobotanical data. Descriptive statistical methods (percentage and frequency) were used to summarize data on reported medicinal plants and associated indigenous knowledge.

\section{Results and discussion}

\section{Socio-demographic characteristics and experience of ethnoveterinary practitioners}

Majority of the ethnoveterinary practitioners surveyed in Fafan zone were rural residents and males. Other studies have similarily shown that practice of Traditional Medicine in Ethiopia is largely dominated by men [25, 37]. Majority of the participants have been practicing ethnoveterinary medicine for $\geq 10$ years. Ethno-veterinary knowledge of the traditional healers was usually obtained from family members or religious institutions (Islamic madrasas) which are passed through generation with word of mouth (Table 1). The way traditional veterinary medicine is acquired by the practitioners is largely similar to traditional human medicine. The traditional healers claimed that there is a considerable overlap in the utilization of some of the reported herbs against both human and livestock diseases. It was also interesting to note that most of the sampled ethnoveterinary practitioners were also traditional healers for several human ailments.
Table 1 Socio-demographic features and ethnoveterinary experiences of participants $(n=24)$

\begin{tabular}{|c|c|c|c|}
\hline Characteristics & Category level & Frequency & Percentage (\%) \\
\hline \multirow[t]{2}{*}{ Sex } & Male & 22 & 91 \\
\hline & Female & 2 & 9 \\
\hline \multirow[t]{3}{*}{ Age } & $25-40$ & 3 & 12 \\
\hline & $41-55$ & 9 & 38 \\
\hline & $56-70$ & 12 & 50 \\
\hline \multirow[t]{2}{*}{ Residence } & Rural & 21 & 88 \\
\hline & Urban & 3 & 12 \\
\hline \multirow[t]{3}{*}{ Educational status } & Formal & 5 & 21 \\
\hline & Religious & 18 & 75 \\
\hline & Illiterate & 1 & 4 \\
\hline \multirow{4}{*}{$\begin{array}{l}\text { Level of } \\
\text { ethnoveterinary } \\
\text { practice experience } \\
\text { (years) }\end{array}$} & $<10$ & 2 & 9 \\
\hline & $10-20$ & 6 & 25 \\
\hline & $21-30$ & 10 & 41 \\
\hline & $>30$ & 6 & 25 \\
\hline \multirow{4}{*}{$\begin{array}{l}\text { Source of } \\
\text { ethnoveterinary } \\
\text { healing knowledge }\end{array}$} & Religious institution & 7 & 29 \\
\hline & $\begin{array}{l}\text { Family members } \\
\text { or decedents }\end{array}$ & 11 & 46 \\
\hline & $\begin{array}{l}\text { Close friends and } \\
\text { colleagues }\end{array}$ & 4 & 16 \\
\hline & $\begin{array}{l}\text { Other senior } \\
\text { traditional healers }\end{array}$ & 2 & 9 \\
\hline \multirow{3}{*}{$\begin{array}{l}\text { Mode of } \\
\text { ethnoveterinary } \\
\text { service delivery }\end{array}$} & Always charging & 3 & 12 \\
\hline & $\begin{array}{l}\text { Sometimes } \\
\text { charging }\end{array}$ & 12 & 50 \\
\hline & $\begin{array}{l}\text { Free (not } \\
\text { charging) }\end{array}$ & 9 & 38 \\
\hline
\end{tabular}




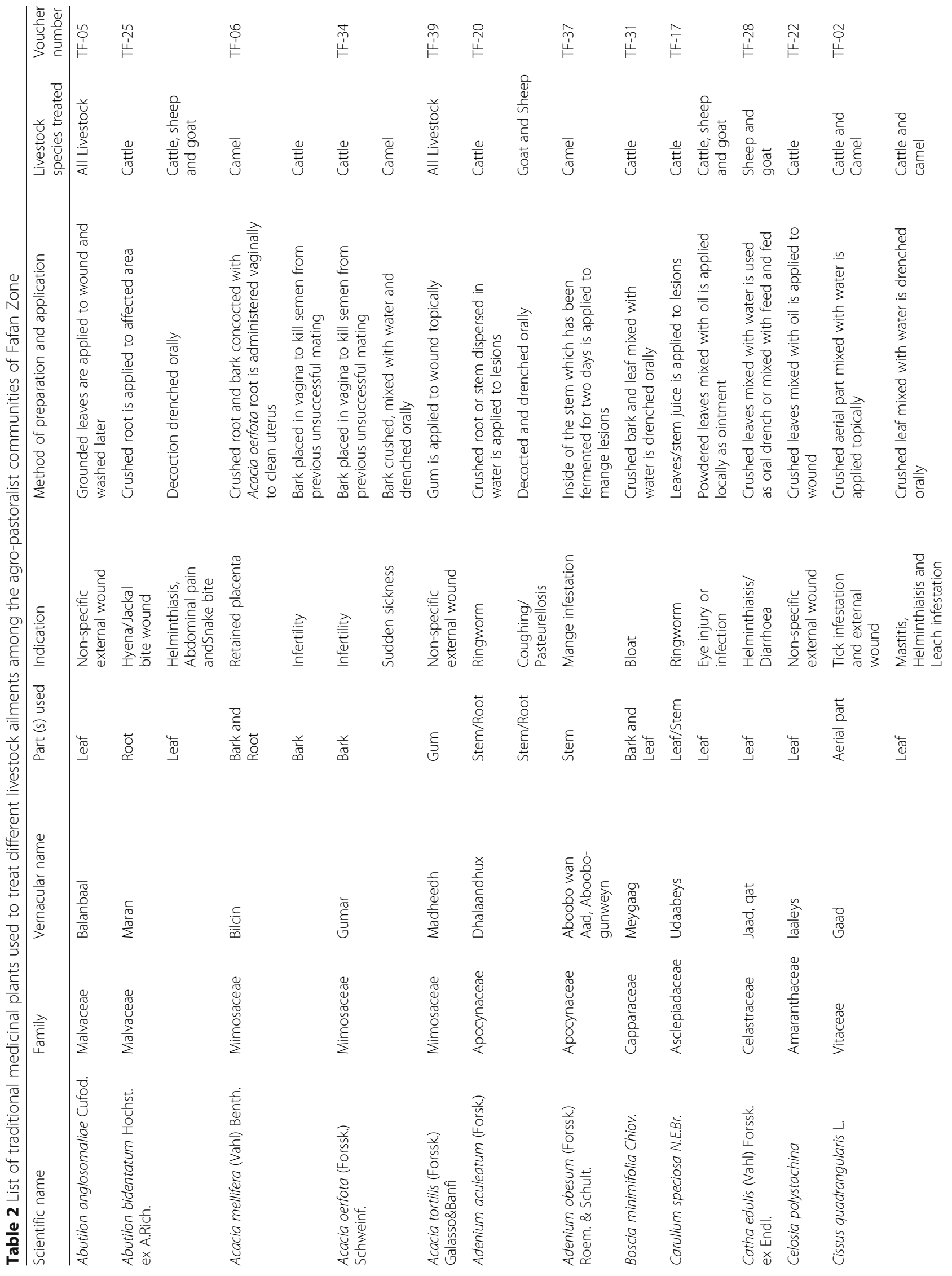




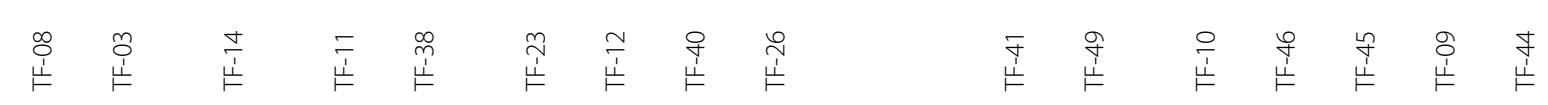

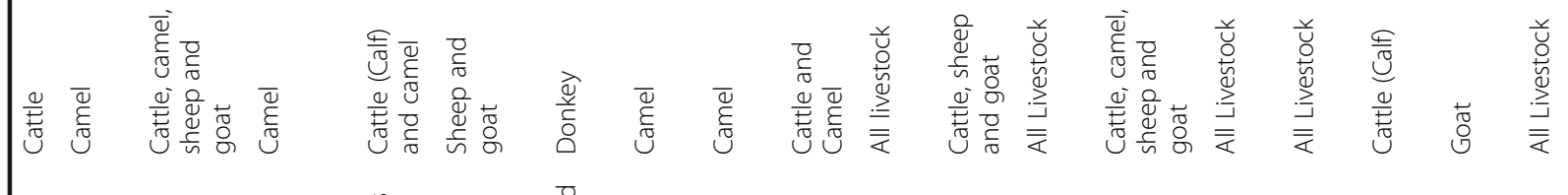

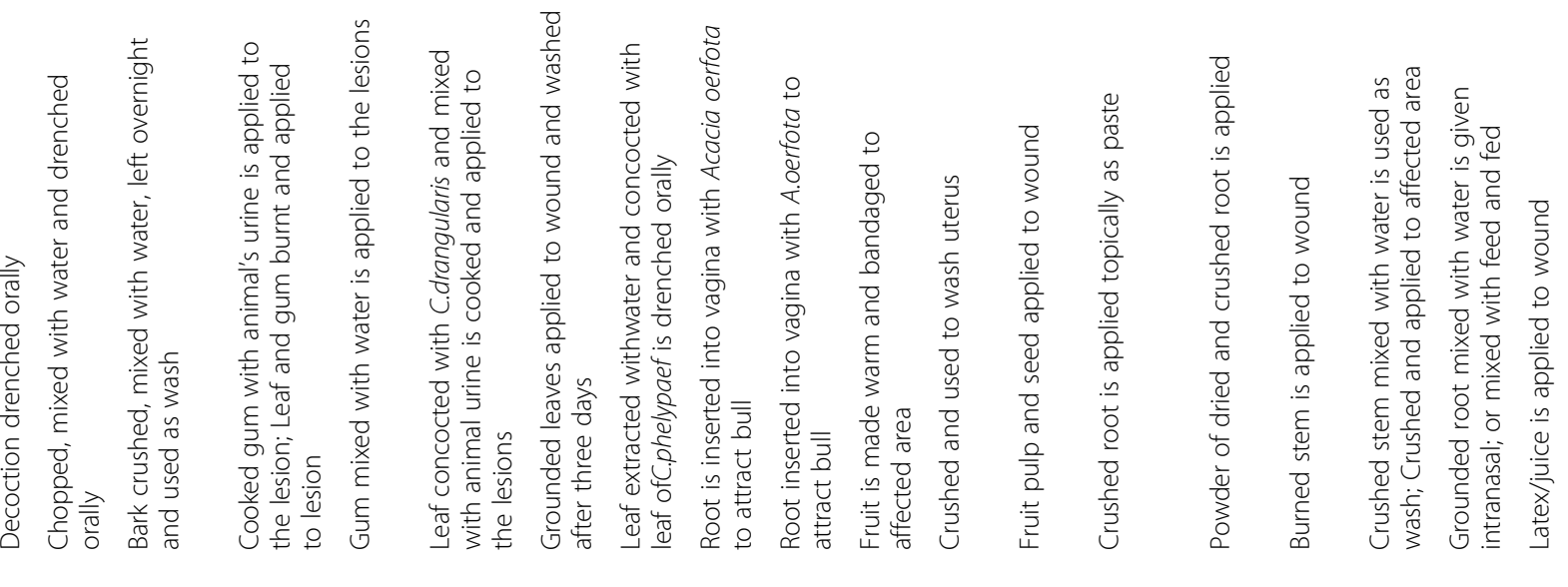

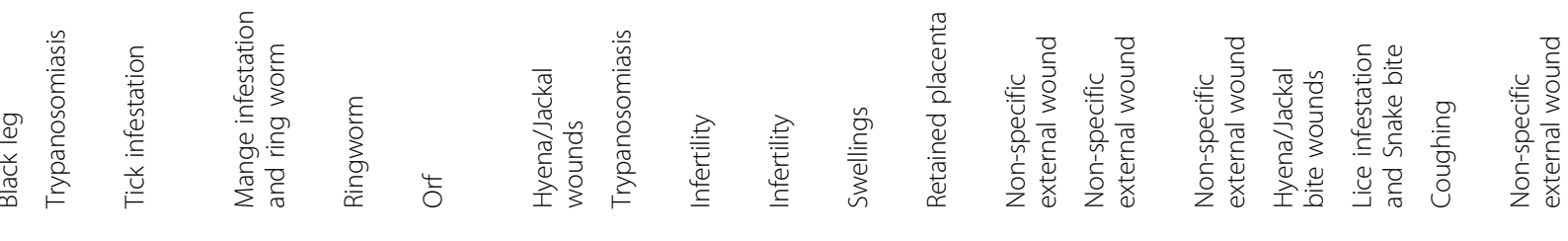

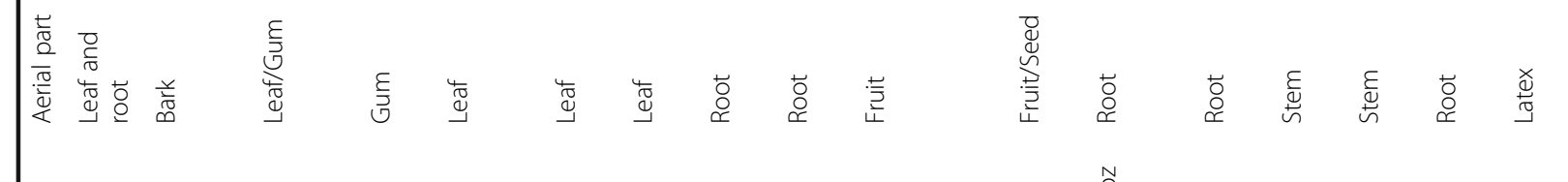

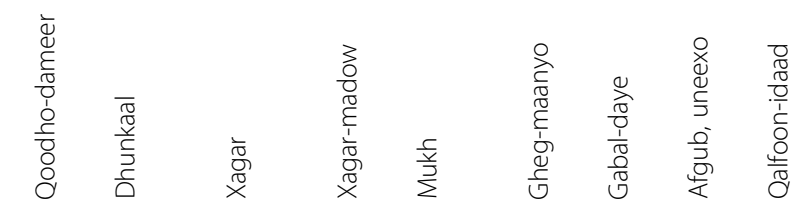

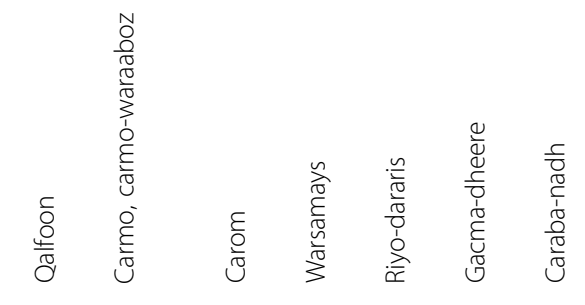




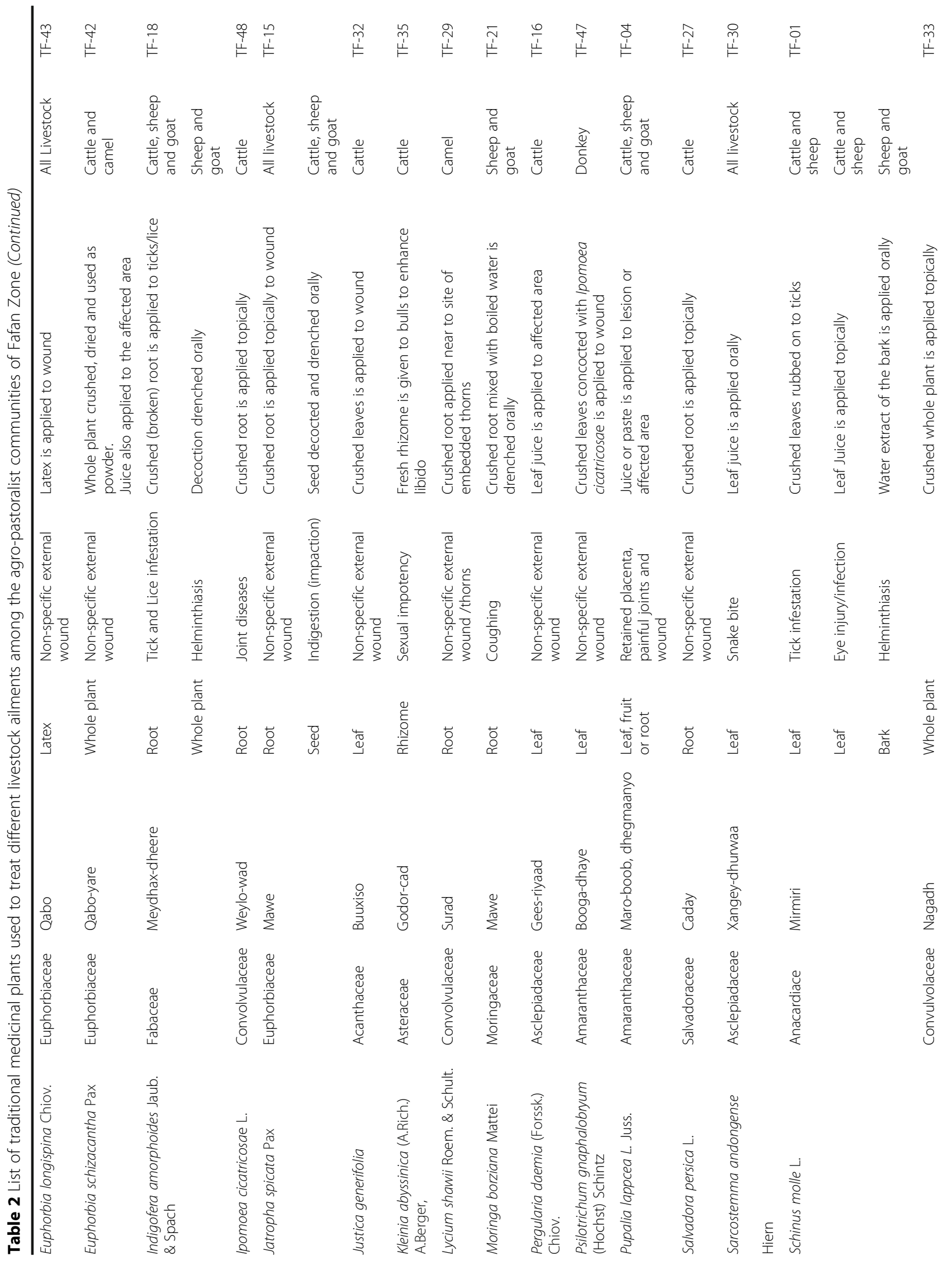




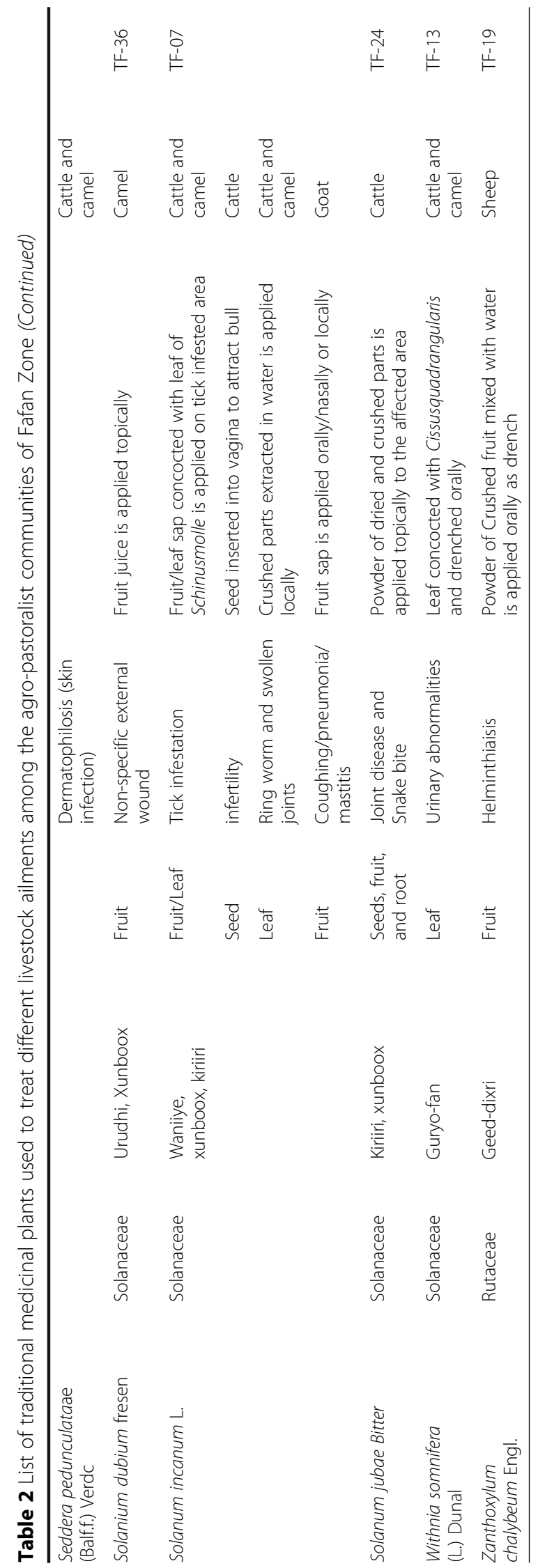




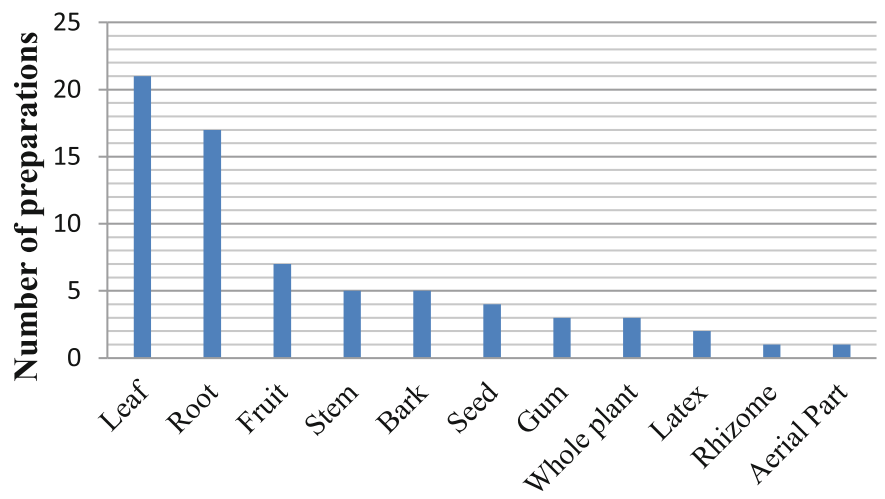

Number of Medicinal plants harvested for specific part

Part Used

Fig. 2 Proportion of plant parts used for preparation of botanical remedies

\section{Documented medicinal plants}

The present study showed that the agro-pastoralist communities in Fafan Zone of ESRS use a variety of medicinal plant species to treat a range of livestock health problems. A total of 49 medicinal plants were reported for the treatment of different livestock ailments. The reported medicinal plants are botanically categorized under 21 plant families (Table 2).

Data from the present study showed that Mimosaceae (5 species), and Solanaceae, Bursuraceace, Asclepiadaceae and Euphorbiaceae (4 species each) took the superior share of the reported plant families, followed by Vitaceae, Amaranthaceae, Cucurbitaceous and Convulvolaceae (3 species each). In agreement with this study, Solanaceae, Bursuraceace and Cucurbitaceous have also been reported to be dominant families in other parts of the country $[25,38-40]$. The fact that Solanaceae, Bursuraceace, Mimosaceae, Asclepiadaceous and Euphorbiaceae contributed relatively higher number of medicinal plants might be attributed to better abundance of species in the study area belonging to these families.
Parts used, mode of preparation and routes of administration

This study revealed that the most frequently used part of plants was leaf (43\%) followed by root (35\%) (Fig. 2). Other parts of the plant reported to be used were fruit (14\%), stem (10\%), bark (10\%), seed, gum, latex, rhizome and aerial parts of the plants. Moreover, the entire plant was used in some cases (6\%). In consonant with the present study, studies conducted elsewhere in Ethiopia indicated that leaves were the most frequently used plant part to treat livestock ailments $[10,22,5,20]$. A study conducted by Poffenberger et al. [41] indicated that collection of leaves for traditional remedies poses no significant threat to the survival of plants in comparison with other parts; such as roots, stem, bark and whole plant. On contrary, harvest involving roots, rhizomes, bulb, bark and stem have a serious threat on the survival of the mother plant in its habitat. In this regard, the present study indicated that root was the second commonly utilized part of the medicinal plant, which shows the presence of high risk on the survival of those reported plants in the study area.

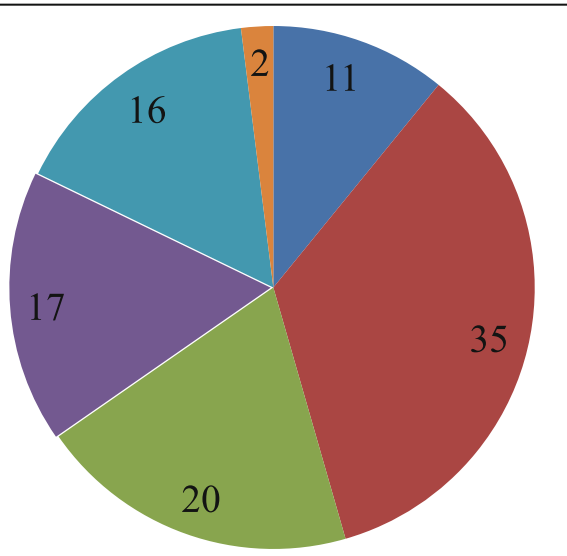

All types of livestock

- Cattle

Camel

- Sheep

Goat

Donkey

Fig. 3 Number of medicinal plants used in different livestock categories in Fafan zone, the area 


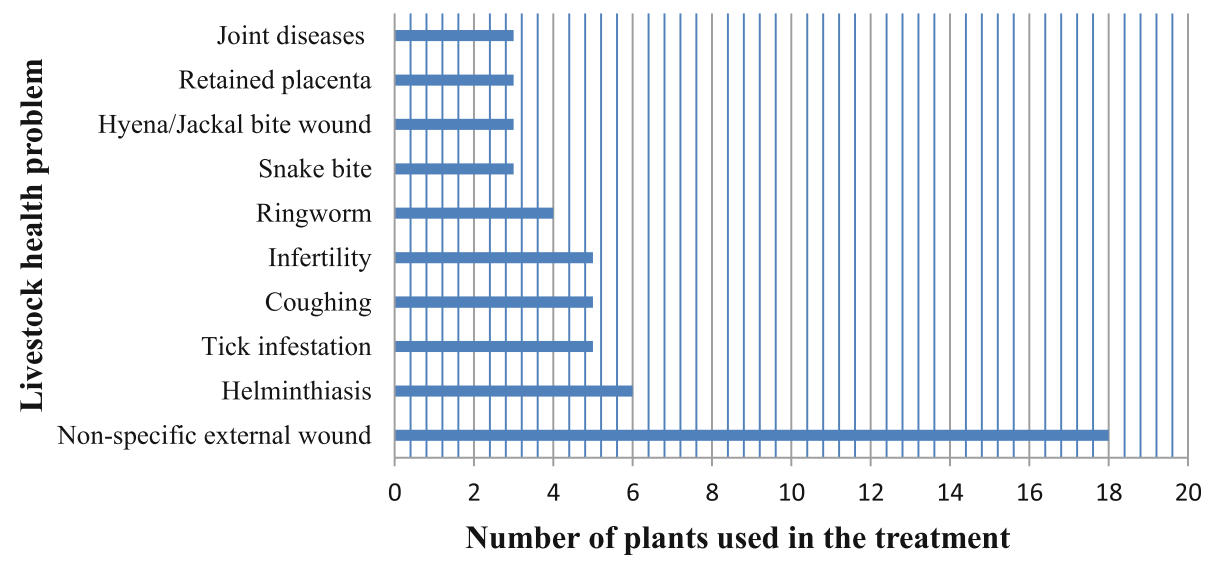

Fig. 4 Livestock health Problems against which three or more medicinal plants have been prescribed

In this study, majority (84\%) of traditional remedies were prepared using a single medicinal plant. Single plant species based preparations also accounted for majority (65\%) of traditional remedies in Afar [5]. However, single plant based preparations were reported at lower frequency from other parts of Ethiopia [22, 42].

In most cases, traditional plant remedies were prepared by pounding the remedial plant part and mixing it with water at room temperature. This is in line with the report of other studies $[39,40]$. Some of the plants are prepared and administered in the form of topical route of administration without mixing using water. Topical applications of paste (poultice), sap, and other formulations were reported by other investigators to be common in traditional veterinary practice [18].

\section{Types of livestock and major livestock health problems treated}

The therapeutic indication of medicinal plant based remedies in Fafan zone covered all livestock species (Fig. 3) and around 29 distinct disease problems. Medicinal plant remedies were more frequently indicated for diseases affecting cattle and camels, followed by small ruminant and equine diseases. This variation is probably a reflection of the abundance and value of different livestock species in the study area rather than the therapeutic range of medicinal plants themselves.

Traditional medicinal plant remedies were prescribed against 29 different types of livestock ailments/health problems (Fig. 4). This study generally revealed that most of the traditional medicines used in the area are used for the management of skin diseases and removal of ecto-parasites. Unspecified wounds were reported to be the indication of majority of medicinal plants (18) (Fig. 4), followed by helminthiasis (6), tick infestation, respiratory disorders characterized by coughing and infertility (5). Out of the 29 animal health problems reported to be treated by ethnobotanical remedies, 15 (51.7\%) are treated by only one medicinal plant species.

\section{Conclusions}

The study suggests that the agro-pastoralist communities of the study area largely depend on ethnoveterinary medicinal plants for the treatment of different animal ailments. In total, 49 medicinal plants were reported to have been used by the ethnoveterinary practitioners and livestock raisers. Leaf followed by root was the most frequently used plant part in the preparation of ethnobotanical remedies. The identified medicinal plants could be potentially useful for future phytochemical and pharmacological studies. Thus, further studies on biological activity, phytoconstituents and safety profile of the reported medicinal plants is warranted.

\section{Abbreviation \\ ESRS: Ethiopian Somali Regional State}

\section{Acknowledgments}

The authors would like to thank the Directorate of Research, Publication and Technology Transfer- Jigjiga University for funding this research. The authors also highly acknowledge the contribution made by local administration and the study participants.

\section{Funding}

This study was financially supported by Jigjiga University.

\section{Availability of data and materials}

The datasets used and/or analyzed during the current study and voucher number of the medicinal plants are available from the corresponding author on reasonable request.

\section{Authors' contributions}

TF conceived, designed and coordinated the study including the process of earning fund. EM and BUW participated in data collection, analysis and drafting the manuscript. SA finalized and submitted the manuscript for publication. All the authors revised and approved the final manuscript.

Ethics approval and consent to participate

Ethical approval was obtained from the Research Ethics Committee of the Directorate of Research, Publication and Technology Transfer, Jigjiga University, Ethiopia. Only respondents who consented to participate in 
the survey were asked to share their knowledge and experience on the use of medicinal plants in their communities to manage animal diseases.

\section{Consent for publication}

Not applicable.

\section{Competing interests}

The authors declare that they have no competing interests.

\section{Publisher's Note}

Springer Nature remains neutral with regard to jurisdictional claims in published maps and institutional affiliations.

\section{Author details}

'Department of Veterinary Clinical Studies, College of Veterinary Medicine, Jigjiga University, Jigjiga, Ethiopia. ²Department of Basic Sciences, College of Medicine and Health Sciences, Jigjiga University, Jigjiga, Ethiopia.

${ }^{3}$ Department of Pharmacology and Clinical Pharmacy, School of Pharmacy, Addis Ababa University, Addis Ababa, Ethiopia.

Received: 6 February 2017 Accepted: 25 July 2017

Published online: 09 August 2017

\section{References}

1. EARO. National Animal Health Research Programme Strategy. Addis Ababa: Ethiopian Agricultural Research Organization (EARO); 1999.

2. Abebe D, Ayehu A. Medicinal plants and enigmatic practices of northern Ethiopia. Addis Ababa: B. S. P. E; 1993. p. 1-200.

3. Wondimu T, Asfaw Z, Kelbessa E. Ethnobotanical study of medicinal plants around "Dheeraa" town Arsi zone, Ethiopia. J Ethnopharmacol. 2007:112:152-61.

4. Zerhiun W, Mesfin T. The status of the vegetation in the Lake region of the Rift Valley of Ethiopia and possibilities of its recovery. SINET: Ethiopian J of Sci. 1990;392:97-120.

5. Giday M, Teklehaymanot T. Ethnobotanical study of plants used in management of livestock health problems by afar people of Ada'ar district, afar regional state, Ethiopia. J Ethnobiol Ethnomed. 2013;9:8.

6. Yineger $\mathrm{H}$, Yewhalaw D. Traditional medicinal plant knowledge and use by local healers in Sekoru District, Jimma zone, southwestern Ethiopia. J Ethnobiol Ethnomed. 2007;3:24. doi:10.1186/1746-4269-3-24.

7. Nasir T, Mohammed A, Nandikola J. Ethnobotanical survey of medicinal plants in the Southeast Ethiopia used in traditional medicine. Spatula. 2011;1:153-8.

8. Kibebew F, Zewdu M, Demissie A. The status of availability of data of oral and written knowledge and traditional health Care in Ethiopia. In: Conservation and sustainable use of medicinal plants in Ethiopia. Addis Ababa: Institute of Biodiversity Conservation and Research; 2001. p. 107-19.

9. Teklehaymanot T, Giday M. Ethnobotanical study of medicinal plants used by people in Zegie peninsula, northwestern Ethiopia. J Ethnobiol Ethnomed. 2007:3-12. doi:10.1186/1746-4269-3-12.

10. Giday M, Ameni $G$. An ethnobotanical survey on plants of veterinary importance in two woredas of southern Tigray, northern Ethiopia. SINET Ethiopian J Sci. 2003;26:123-36

11. Endashaw B. Study on actual situation of medicinal plants in Ethiopia Prepared for JAICAF (Japan Association for International Collaboration of Agric and Forestry). 2007. http://www.jaicaf.or.jp/publications/ethiopia_ac. pdf. Accessed 17 Mar 2017.

12. Hoff W. Traditional practitioners as primary health care workers. Geneva: WHO; 1995. p. 141

13. Gessese B. Review of land degradation and land management in Ethiopia up to 2008/09. In: Edwards S, editor. Ethiopian environment review; 2010. p. 187-214.

14. Berhan $G$, Dessie S. Medicinal plants in Bonga Forest and their uses. In Biodiversity newsletter I Addis Ababa:IBCR. 2002; 9-10.

15. Pankhurst R. The status and availability of oral and written knowledge on traditional health care in Ethiopia. In: Proceedings of the National Workshop on biodiversity conservation and sustainable use of medicinal plants in Ethiopia. Addis Ababa: IBCR; 2001. p. 92-106.
16. Hamilton AC. Medicinal plants and conservation: issues and approaches. UK: International plant conservation unit, WWF-UK, Pandahouse, Catteshall Lane; 2003.

17. Gidey A (2009). A study on traditional medicinal plants of Central Tigray. A senior essay submitted to the department of biology in partial fulfillment of the requirements for bachelor degree, Mekelle University, Ethiopia.

18. Sori T, Bekana M, Adunga G, Kelbesa E. Medicinal plants in ethnoveterinary practices of borana pastoralists, southern Ethiopia. Int J Appl Res Vet Med. 2004:2:220-5.

19. Yirga G. Assessment of indigenous knowledge of medicinal plants in central zone of Tigray, northern Ethiopia. African J Plant Sci. 2010;4(1):006-11.

20. Yirga G, Teferi M, Gidey G, Zerabruk S. An ethnoveterinary survey of medicinal plants used to treat livestock diseases in Seharti-Samre district, northern Ethiopia. African J Plant Sci. 2012;6(3):113-9.

21. Kebu B, Ensermu K, Zemede A. Indigenous medicinal utilization, management and threats in Fentale area, eastern Shewa, Ethiopia. Ethiop J Biol Sci. 2004:3(1):37-58.

22. Hunde D, Asfaw Z, Kelbessa E. Use and management of ethnoveterinary medicinal plants by indigenous people in 'Boosat', Welenchiti area. Ethiopian J Biol Sci. 2004;3:113-32.

23. Yineger $\mathrm{H}$, Kelbessa $\mathrm{E}$, Bekele $\mathrm{T}$, Lulekal E. Ethnoveterinary medicinal plants in Bale Mountains National Park, Ethiopia. J Ethnopharmacol. 2007;112:55-70.

24. Yineger $H$, Yewhalaw D, Teketay D. Plants of veterinary importance in southwestern Ethiopia: the case of Gilgel Ghibe area. Forests Trees Livelihoods. 2008;18(2):165-81.

25. Yigezu Y, Berihun D, Yenet W. Ethnoveterinary medicines in four districts of Jimma zone, Ethiopia: cross sectional survey for plant species and mode of use. BMC Vet Res. 2014:10:76. doi:10.1186/1746-6148-10-76.

26. Tekle Y. Study on ethno veterinary practices in Amaro special district southern Ethiopia. Med Aromat Plants. 2015:4:186. doi:10.4172/21670412.1000186

27. Melaku A. Ethnoveterinary practices and potential herbal materials for the treatment of ticks in North Gondar. Global Veterinaria. 2013;11(2):186-90.

28. Birhanu T, Gadisa M, Gurmesa F, Abda S. Survey on Ethno-Veterinary Medicinal Plants in Selected Woredas of East Wollega Zone, Western Ethiopia. J. Biol. Agric. Healthcare. 2014:4(17):97-105.

29. IPS (Industrial Project Service). Resource potential assessments and project identification study of Somali region. Vol.3. Agricultural Resources.Industrial projects service; 2002. p. 401.

30. National Meteorological Services Agency (NMSA). Annual Climatic Bulletin. Addis Ababa: Ministry of Water Resources; 2004. p. 16.

31. Milkessa W, Kurtu MY. Small scale dairy development project (SDDP). Studies and planning for the establishment of small scale dairy production. Alemay: Alemaya University of Agriculture; 1997. p. 44.

32. Russell B. Research methods in anthropology: qualitative and quantitative methods. 3rd edition, ISBN-10: 0759101485 (ISBN-13: 978-0759101487). California: Altamira Press; 2002

33. Alexiades MN. Selected guidelines for Ethnobotanical research: a field manual. In: Advances in economic botany volume 10. The New York Botanical Garden: Bronx; 1996.

34. Martin GJ. Ethnobotany. A methods manual. London: WWF for Nature International, Chapman and Hall, London; 1995. p. 265-70.

35. Edwards S, Tadesse M, Demissew S, Hedberg I (Eds): Flora of Ethiopia and Eritrea. Volume 2, part 1. Magnoliaceae to Flacourtiaceae. The National Herbarium, Addis Ababa, Ethiopia, and Department of Systematic Botany, Uppsala, Sweden; 2000.

36. Hedberg I, Edwards S, Nemomissa S (Eds): Flora of Ethiopia and Eritrea. Volume 4, part 1. Apiaceae to Dipsacaceae. The National Herbarium, Addis Ababa, Ethiopia, and Department of Systematic Botany, Uppsala, Sweden; 2003

37. Addis G, Abebe D, Urga K. A survey on traditional medicinal plants in Shirka district Arsi zone, Ethiopia. EPJ. 2001;19:30-47.

38. Gebrezgabiher G, Kalayou S, Sahle S. An ethnoveterinary survey of medicinal plants in woredas of Tigray region, northern Ethiopia. Int J Biodivers Conserv. 2013;5:89-97.

39. Tamiru F, Terfa W, Kebede E, Dabessa G, Roy RK, Sorsa M. Ethnoknowledge of plants used in veterinary practices in Dabo Hana District, West Ethiopia. J Med Plants Res. 2013:7:2960-71.

40. Lulekal E, Kelbessa E, Bekele T, Yineger H. An ethnobotanical study of medicinal plants in Mana Angetu District, southwestern Ethiopia. J Ethnobiol Ethnomed. 2008;4:10. 
41. Poffenberger M, McGean B, Khare A, Campbell J. Community Forest economy and use pattern: participatory rural Apraisal method in South Gujarat, India. Field method manual volume II. Society for promotion of Wastelands Development: New Delhi; 1992.

42. Giday M, Asfaw Z, Woldu Z. Ethnomedicinal study of plants used by Sheko ethnic group of Ethiopia. J Ethnopharmacol. 2010;132:75-85.

Submit your next manuscript to BioMed Central and we will help you at every step:

- We accept pre-submission inquiries

- Our selector tool helps you to find the most relevant journal

- We provide round the clock customer support

- Convenient online submission

- Thorough peer review

- Inclusion in PubMed and all major indexing services

- Maximum visibility for your research

Submit your manuscript at www.biomedcentral.com/submit 